\title{
Polymorphisms in the glutathione S-transferase theta and mu genes and susceptibility to myeloid leukemia in Brazilian patients
}

\author{
Claudio Lima Souza ${ }^{1}$, Cynara Gomes Barbosa ${ }^{1}$, José Pereira de Moura Neto ${ }^{1,2}$, José Henrique Barreto ${ }^{3}$, \\ Mitermayer Galvão Reis ${ }^{1}$ and Marilda Souza Gonçalves ${ }^{1,2}$ \\ ${ }^{1}$ Laboratório de Patologia e Biologia Molecular, Centro de Pesquisas Gonçalo Moniz, \\ Fundação Oswaldo Cruz, Salvador, BA, Brazil. \\ ${ }^{2}$ Departamento de Análises Clínicas e Toxicológicas, Faculdade de Farmácia, \\ Universidade Federal da Bahia, Salvador, BA, Brazil. \\ ${ }^{3}$ Clínica Onco, Salvador, BA, Brazil.
}

\begin{abstract}
The null genotype for glutathione S-transferase (GST, EC 2.5.1.18) gene polymorphisms is considered a risk factor for leukemia in different populations. In this work we investigated the GSTT1 and GSTM1 polymorphisms using multiplex PCR in 53 patients with chronic myeloid leukemia (CML), 23 with acute promyelocytic leukemia (APL) and 304 apparently healthy controls. In this association study we found that the GSTT $1^{\text {null }}$ genotype was more frequent in our group of APL patients than in the control group $[\mathrm{OR}=2.75(95 \% \mathrm{Cl}=1.10-6.88)]$, providing evidence that a deletion in the GSTT1 gene could be a risk factor for this type of leukemia.
\end{abstract}

Key words: acute promyelocytic leukemia, chronic myeloid leukemia, GSTM1, GSTT1, gene polymorphism.

Received: April 27, 2007; Accepted: October 1, 2007.

Leukemias are complex diseases determined by a combination of several factors. It has been shown that DNA damage in hematopoietic precursor cells is directly linked to the risk of acute leukemia in adults (Rollinson et al., 2000) and may results from an interaction between reactive species generated by environmental or endogenous metabolites (Rollinson et al., 2000; Dalo et al., 2004). Human cells possess metabolic systems to eliminate toxic agents and several enzymes are responsible for the degradation of these xenobiotics, one systems being the glutathione S-transferase (GST, EC 2.5.1.18) group of enzymes which detoxify environmental carcinogens by conjugation with glutathione (Crump et al., 2000). The GST group is known to be coded for by 16 genes in six GST subfamilies, known as alpha (GSTA), mu (GSTM), omega (GSTO), pi (GSTP), theta $(G S T T)$ and zeta (GSTZ). Two widespread genetic polymorphisms that involve deletions in GSTT1 and GSTM1 have been reported to lead to loss of enzyme activity (Bolufer et al., 2007) and have been investigated in many different populations, including those from Japan (Naoe et al., 2000), Italy (D'alo et al., 2004) and Spain (Bolufer et al., 2007). Furthermore, several studies have proposed that susceptibility to acute and chronic myeloid

Send correspondence to Marilda Souza Gonçalves. Centro de Pesquisas Gonçalo Moniz, Fundação Oswaldo Cruz, Rua Waldemar Falcão 121, 40296-710 Salvador, BA, Brazil. E-mail: mari@bahia. fiocruz.br. leukemia (AML and CML respectively) could be related to GSTT1 and/or GSTM1 deletions (Rollinson et al., 2000; Mondal et al., 2005; Ye and Song, 2005.

Brazil is the largest country in South America, with a highly heterogeneous population due to several waves of immigration which have resulted in cultural, socioeconomic and ethnic diversity. In the Northeastern Brazilian state of Bahia, which has a highly mixed population of mainly African descent, the largest city is Salvador (population 2.7 million; RIPSA, 2006), $86 \%$ of the local population being of African, or European and African, descent. A recent study by Barreto et al. (2006) reported that the Bahian population shows a high prevalence of pediatric acute promyelocytic leukemia (APL), which accounted for $21 \%$ of all AML patients $(\mathrm{n}=105)$ evaluated between 1995 and 2004). Ribeiro and Rego (2006) reported that patients with a Latin American background (i.e. some Amerindian genetic input) were much more likely to have APL (18.2\%) than were white (7.7\%) or black (10.3\%) patients without a Latin American background. Based on this, we decided to investigate the frequency of GSTT1 and GSTM1 polymorphisms among patients with APL and CML from the city of Salvador.

We investigated a total of 76 patients with myeloid leukemia, 53 (30 (57\%) male, 23 (43\%) female; mean age $41 \mathrm{y} \pm$ a standard deviation (SD) of $21 \mathrm{y}$ ) with CML and 23 (11 (48\%) male, 12 (52\%) female; mean age $14 \mathrm{y} \pm 6.8 \mathrm{y}$ ) with APL which were selected at diagnosis between 2000 
and 2003 from several institutions that attend patients with malignant diseases. Most of the APL cases were from a pediatric oncological institute (Clínica de Oncologia, Salvador, Bahia). The control group consisted of 304 (131 (43.2\%) male, $173(56.8 \%)$ female ; mean age $29 \mathrm{y} \pm 9.5 \mathrm{y})$ was composed of apparently healthy individuals randomly chosen from the staff of a private clinical laboratory (Labcheckup, Pituba, Salvador, Bahia). Both patients and control individuals all came from Bahia. The diagnoses of leukemia were made according to clinical, morphological and molecular criteria and the study was approved by the Oswaldo Cruz Research Foundation's Human Research Ethics Committee. Bone marrow and peripheral blood samples were obtained only after an informed consent form was signed.

We extracted RNA, using Trizol ${ }^{\mathrm{R}}$ (Gibco-BRL, Life Technologies, USA), and DNA, using Genomic Blood DNA Purification Kits (Amersham Pharmacia Biotech, USA), from bone marrow cells and peripheral blood leukocytes according to the guidelines of the manufacturer. The translocations $\mathrm{t}(9 ; 22)(\mathrm{q} 34 ; \mathrm{q} 11)$ for $\mathrm{CML}$ and $\mathrm{t}(15 ; 17)(\mathrm{q} 22$; q12-21) for APL patients were investigated using the reverse transcriptase polymerase chain reaction PCR (RTPCR) method according to the methodology of Biernaux et al. (1995) and Miller et al. (1993). The GST polymorphisms were assessed using the multiplex PCR method described by Arruda et al. (2001), using the $\beta$-globin gene as an internal control.

Descriptive analyses included genotype frequencies and the odds ratio (OR) as an estimate of relative risk, with 95\% confidence intervals (CI). Chi-square test using the Yates correction or the Fisher's exact test were applied and differences were considered significant at the $\mathrm{p}$ level. All analyses were carried out using the EPI INFO software, version 6.04 (Centers for Disease Control and Prevention, Atlanta, GA, USA).

All 53 CML patients had the $\mathrm{t}(9 ; 22)(\mathrm{q} 34 ; \mathrm{q} 11)$ translocation and all 23 APL patients had the $\mathrm{t}(15 ; 17)(\mathrm{q} 22$; q11-21) translocation. The frequencies of the GSTT1 and the GSTM1 genotypes in both patients and controls are presented in Table 1. Although we found similar patterns for the GST multiplex PCR it is possible that the loss of heterozygosity in peripheral blood or bone marrow cells may have increased the frequencies of the GSTMI $1^{\text {null }}$ and GSTT1 $^{\text {null }}$ genotypes. However, the frequency distributions of these polymorphisms were in agreement with the Hardy-Weinberg equilibrium. No association was found between the GSTT1 or GSTM1 deletions and CML risk in the group studied but there was an increased APL risk for the $G S T T 1^{\text {null }} / G S T M 1^{\text {normal }}(\mathrm{OR}=2.75,95 \% \mathrm{CI}=1.1$ to $6.88)$ and $G S T T 1^{\text {null }} / G S T M 1^{\text {null }}(\mathrm{OR}=3.61,95 \% \mathrm{CI}=1.37$ to 9.51) genotypes (Table 1).

Several studies associating the presence of the GSTM1 and GSTT1 polymorphisms with lymphoid and myeloid leukemias have been performed (Crump et al., 2000; Naoe et al., 2000; Dalo et al., 2004; Mondal et al., 2005; Bolufer et al., 2007). Our analyses showed that the GSTT1 gene deletion was significantly higher among Brazilian APL patients than controls but no association was observed between APL susceptibility and the isolated GSTM ${ }^{\text {null }}$ genotype, although when the $G S T M 1^{\text {null }} / G S T T 1^{\text {null }}$ genotype was considered there was a significant difference between the APL group and the control group. The APL type of disease is a FrenchAmerican-British (FAB, Bennett et al., 1976) classification subtype leukemia, also named AML-M3, frequently presenting the $\mathrm{t}(15 ; 17)(\mathrm{q} 22 ; \mathrm{q} 12-21)$ translocation. We suppose that the deletions may lead to lack of detoxification of electrophilic compounds and/or a higher DNA damage ratio, which could contribute to the development and proliferation of leukemia.

Rollinson et al. (2000) observed similar results, but found a weaker association between the GSTM1 or GSTT1 deletions and increased risk to AML, the same FABsubtype leukemia, in British adults. The differences between these studies may be related to age variation or to the diverse genetic backgrounds of the patients. Arruda et al. (2001) found an association between the development AML and the GSTM1 $1^{\text {null }}$ or GSTT1 ${ }^{\text {null }}$ genotypes among Brazilian individuals, but they did not separate the FAB subgroups.

Ye and Song (2005) performed a systematic review of several studies of GST gene polymorphisms in relation to the risk of acute leukemia, their results suggesting that the $G S T M 1^{\text {null }}$ and GSTT1 $1^{\text {null }}$ genotypes are not associated with AML. Our results, however, surprisingly showed a differ-

Table 1 - The glutathione S-transferase (GST) GSTT1 and GSTM1 polymorphism genotype distribution plus the odds ratio (OR) and $95 \%$ confidence intervals $(\mathrm{CI})$ for acute promyelocytic leukemia (APL) patients $(\mathrm{n}=23)$ and chronic myeloid leukemia $(\mathrm{CML})$ patients $(\mathrm{n}=53)$ as compared to apparently healthy control individuals $(\mathrm{n}=304)$.

\begin{tabular}{|c|c|c|c|c|c|c|c|}
\hline \multirow[b]{2}{*}{ GST genotype } & \multirow{2}{*}{$\begin{array}{l}\text { APL, } \\
\text { n (\%) }\end{array}$} & \multirow{2}{*}{$\begin{array}{l}\text { CML, } \\
\text { n (\%) }\end{array}$} & \multirow{2}{*}{$\begin{array}{l}\text { Control, } \\
\text { n (\%) }\end{array}$} & \multicolumn{2}{|c|}{ APL $v s$. controls } & \multicolumn{2}{|c|}{ CML vs. controls } \\
\hline & & & & OR $(95 \% \mathrm{CI})$ & $\mathrm{p}$ value & OR $(95 \% \mathrm{CI})$ & $\mathrm{p}$ value \\
\hline GSTM1 $1^{\text {normal }} /$ GSTT1 $1^{\text {normal }}$ & $7(30.4)$ & $28(52.8)$ & $165(54.2)$ & $1 *$ & & $1^{*}$ & \\
\hline GSTM1 $1^{\text {null }} /$ GSTT $^{\text {normal }}$ & $7(30.4)$ & $15(28.3)$ & $100(33.0)$ & $0.89(0.32$ to 2.40$)$ & $0.80^{\dagger}$ & $0.83(0.48$ to 1.45$)$ & $0.61^{\dagger}$ \\
\hline GSTM $1^{\text {normal }} /$ GSTT1 $1^{\text {null }}$ & $5(21.7)$ & $8(15.1)$ & $25(8.2)$ & $2.75(1.10$ to 6.88$)$ & $0.04^{\ddagger}$ & $1.75(0.90$ to 3.38$)$ & $0.09^{\dagger}$ \\
\hline GSTM1 $1^{\text {null }} /$ GSTT $1^{\text {null }}$ & $4(17.5)$ & $2(3.8)$ & $14(4.6)$ & $3.61(1.37$ to 9.51$)$ & $0.02^{\dagger}$ & $1.85(0.47$ to 7.22$)$ & $0.31^{\dagger}$ \\
\hline Total & 23 & 53 & 304 & & & & \\
\hline
\end{tabular}

*Reference group $(\mathrm{OR}=1.0) ;{ }^{\dagger} \mathrm{Chi}-$ square test/Yates correction; ${ }^{\dagger}$ Fisher's exact test. 
ent pattern of GSTT1 polymorphism frequency among the APL patient group. Since the GSTT1 enzyme is responsible for the detoxification of environmental xenobiotics these results may be associated with high rates of APL in the investigated population. Barragan et al. (2007) recently suggested the influence of GST deletions on treatment follow up after chemotherapy in adult non-promyelocytic patients.

We observed similar frequencies in CML patients and controls but Lourenco et al. (2005) found a lower frequency of the GSTT1 ${ }^{\text {null }}$ genotype in CML Brazilian patients who were both in the blast crisis or in the chronic phase, while Mondal et al. (2005) observed an increase in the GSTT1 ${ }^{\text {null }}$ genotype in CML patients from India.

Our population was composed of an admixture of Amerindian, African and European-derived subjects, and the GST polymorphisms is known to exhibit different frequencies according to ethnic group (Gattas et al., 2004). Our results were different from those for individuals of European-descent from the Southeastern Brazilian state of São Paulo reported by Gattas et al. (2004), who found frequencies of 22.3 for the GSTT1 ${ }^{\text {null }}$ and $55.4 \%$ for the tGSTM $1^{\text {null }}$ genotypes. This difference can be explained by the high percentage of African genes present in Salvador population.

In conclusion, our analyses suggest that the GSTT1 genetic background might be an important marker for APL risk, at least in Salvador.

\section{Acknowledgments}

This research was supported by the State of Bahia Research Support foundation (Fundação de Amparo à Pesquisa do Estado da Bahia, FAPESB) by award numbers 277/04 to CGB and 1431030005540 to MSG and by the Brazilian National Counsel for Scientific and Technological Development (Conselho Nacional de Desenvolvimento Científico e Tecnológico, CNPq) for grant number 306524/ 2004-0 to MSG.

\section{References}

Arruda VR, Lima CS, Grignoli CR, De Melo MB, Lorand-Metze I, Alberto FL, Saad ST and Costa FF (2001) Increased risk for acute myeloid leukaemia in individuals with glutathione S-transferase mu 1 (GSTM1) and theta 1 (GSTT1) gene defects. Eur J Haematol 66:383-388.

Barragan E, Collado M, Cervera J, Martin G, Bolufer P, Roman J and Sanz MA (2007) The GST deletions and NQO1*2 polymorphism confers interindividual variability of response to treatment in patients with acute myeloid leukemia. Leuk Res 31:947-953.

Barreto JHS, Rego MV, Robazi TCV, Dorea MDF, Souto BHL, Sousa DAL, Coelho ED, Santana MACC and Mendonça N (2006) Leucemia não-linfocítica aguda na infância e adolescência. Anais do Congresso Brasileiro de Oncologia Pediátrica, AO 23. Online: http://www.oncopediatria.org. br/portal/hotsites/congressoX/view.jsp?valor $=\mathrm{AO}$ xml/ OP-AO-23\&estilo=apres.

Bennett JM, Catovsky D, Daniel MT, Flandrin G, Galton DA, Gralnick HR and Sultan C (1976) Proposals for the classifi- cation of the acute leukaemias. French-American-British (FAB) co-operative group. Br J Haematol 33:451-458.

Biernaux C, Loos M, Sels A, Huez G and Stryckmans P (1995) Detection of Major bcr-abl gene expression at a very low level in blood cells of some healthy individuals. Blood 86:3118-3122.

Bolufer P, Collado M, Barragán E, Cervera J, Calasanz MJ, Colomer D, Roman-Gómez J and Sanz MA (2007) The potential effect of gender in combination with common genetic polymorphisms of drug-metabolizing enzymes on the risk of developing acute leukemia. Haematologica 92:308-314.

Crump C, Chen C, Appelbaum FR, Kopecky KJ, Schwartz SM, Willman CL, Slovak ML and Weiss NS (2000) Glutathione S-transferase theta 1 gene deletion and risk of acute myeloid leukemia. Cancer Epidemiol Biom Prev 9:457-460.

D'alo F, Voso MT, Guidi F, Massini G, Scardocci A, Sica S, Pagano L, Hohaus S and Leone G (2004) Polymorphisms of CYP1A1 and glutathione S-transferase and susceptibility to adult acute myeloid leukemia. Haematologica 89:664-670.

Gattas GJ, Kato M, Soares-Vieira JA, Siraque MS, Kohler P, Gomes L, Rego MA and Bydlowski SP (2004). Ethnicity and glutathione S-transferase (GSTM1/GSTT1) polymorphisms in a Brazilian population. Braz J Med Biol Res 337:451-458.

Lourenco GJ, Ortega MM, Nascimento H, Teori MT, De Souza CA, Costa FF and Lima CCS (2005) Polymorphisms of glutathione S-transferase mul (GSTM1) and theta 1 (GSTT1) genes in chronic myeloid leukaemia. Eur J Haematol 75:530-531.

Miller Jr WH, Levine K, DelBlasio A, Frankel SR, Dmitrovsky E and Warrell Jr RP (1993) Detection of minimal residual disease in acute promyelocytic leukemia by a reverse transcription polymerase chain reaction assay for PML/RAR- $\alpha$ fusion mRNA. Blood 82:1689-1694.

Mondal BC, Paria N, Majumdar S, Chandra S, Mukhopadhyay A, Chaudhuri U and Dasgupta UB (2005) Glutathione S-transferase M1 and T1 null genotype frequency in chronic myeloid leukaemia. Eur J Cancer Prev 14:281-284.

Naoe T, Takeyama K, Yokozawa T, Kiyoi H, Seto M, Uike N, Ino T, Utsunomiya A, Maruta A, Jin-nai I et al. (2000) Analysis of genetic polymorphism in NQO1, GST-M1, GST-T1, and CYP3A4 in 469 Japanese patients with therapy-related leukemia/myelodysplastic syndrome and de novo acute myeloid leukemia. Clin Cancer Res 6:4091-4095.

Ribeiro RC and Rego E (2006) Management of APL in developing countries: Epidemiology, challenges and opportunities for international collaboration. Hematology Am Soc Hematol Educ Program, pp 162-168.

Rollinson S, Roddam P, Kane E, Roman E, Cartwright R, Jack A and Morgan GGJ (2000) Polymorphic variation within the glutathione S-transferase genes and risk of adult acute leukemia. Carcinogenesis 21:43-47.

Ye Z and Song H (2005) Glutathione s-transferase polymorphisms (GSTM1, GSTP1 and GSTT1) and the risk ofacute leukaemia: A systematic review and meta-analysis. Eur J Cancer 41:980-989.

\section{Internet Resource}

RIPSA - Rede Interagencial de Informações para Saúde - 2006. Indicadores e Dados Básicos - Brasil - 2006. http://tabnet. datasus.gov.br/cgi/idb2006/matriz.htm.

Associate Editor: Francisco Mauro Salzano 